\title{
Managerial Decision Support Making in Economic Systems Based on Cognitive Modeling
}

\author{
L. Filipkovska $^{1 *}$, O. Matviienko ${ }^{1}$ \\ ${ }^{1}$ National Aerospace University named after M.Y. Zhukovsky "Kharkiv Aviation Institute" \\ *Corresponding author E-mail: l.filipkovska@gmail.com
}

\begin{abstract}
The research is devoted to the search for the technologies to support managerial decisions in the transport industry economic systems. The problems of the complex economic systems modelling have been identified. Cognitive modelling is considered as a tool of supporting intelligent decision making in economic systems. The modelling is based on methods of pattern recognition theory. The results of the scientific research are presented with structural-analytical models of decision support systems. Such models represent the knowledge processing to formulate recommendations for making managerial decisions. Knowledge based on the experience of managing a production situation should be stored in the knowledge base of the information decision making support system. Cognitive modeling will make it possible to study the problems that arise in unstable, weakly structured dynamic economic systems, taking into account changes of the external environment and the object of management itself, systematizing and verifying the expert's perception of the management object and its external environment, forecasting the values of economic system factors and generating optimal management strategies.
\end{abstract}

Keywords: cognitive modeling; decision trees; economic systems; managerial decision support; methods of pattern recognition theory.

\section{Introduction}

Management as a function of ensuring the life of the economic system is aimed at making decisions. Managerial decisions are formed for the implementation of a set of interrelated, purposeful and logically consistent actions that will contribute to the achievement of the purposes of such a system [1].

The tasks of management of the economic system are substantially weakly structured and poorly formalized; they contain contradictory purposes and criteria, and require a variety of ways to solve problems with fuzzy knowledge, aims, and data. When solving them, the following uncertainties arise:

- subjects insufficient knowledge about management problems;

- impossibility of taking into account the environment reaction;

- incompleteness of data on the effectiveness of the economic system elements.

The problem actuality of the complex economic systems functioning in crisis situations has created the need to develop a methodology for modelling complex systems that develop with incomplete knowledge and weak formalization of tasks.

The main problem when creating a rational system of an economic object management consists in the choice or development of a mathematical model that provides adjustment to the specifics of the management object through the use of a posteriori information about its and the environment, as well as due to additional on-line information during the system exploitation.

The purposes of the work are to study the issues of cognitive analysis and the theoretical basis of cognitive technologies for making managerial decisions in economic systems.

\section{Literature Review}

The economic system is a set of interrelated and properly adjusted elements that form a certain integrity and determine the method of organizing the economic life activity of society [2]. The concept of the economic system is used to identify and characterize the status of productive forces, the structure of the economy, economic relations, forms of economic management, the totality of institutions and elements of the superstructure [3, 4]. Under conditions of uncertainty of the environment it is actual formation of strategic guidelines for the development of economic systems [5]. This tendency is characterized primarily by qualitative changes [6].

Modern enterprise is considered as an economic system characterized by a variety of structure, the difference nature of elements and their complex relationships, the dynamism, which consists in the continuous change of status of the specified system, multicriteria and probabilistic nature of production processes.

Today, the problems of crisis management of the enterprise, prevention of conflicts, bankruptcy, reduction of economic, social and moral losses from them, formation of the strategy of organizing changes and innovations, development of marketing strategies for survival in the market are put on the foreground [7]. The economic status of the object of management as a complex economic phenomenon depends on the set of indicators set by the researcher, the variability of values of which is determined by a set of conditions, from the methods of evaluation of this state and from the chosen criterion of classification and classification scale [2], [5].

The theoretical and methodological evaluation of the efficiency of the functioning of the economic system is no less relevant [8-10]. One of the most important directions of improving the efficiency 
of the enterprise is the introduction of reengineering and restructuring instruments in the field of manufacturing business. Therefore, in order to ensure the competitive strength of the economic system, business reengineering is currently being proposed [11].

Complexity, diversity, combination of instability and stability, variability and inertia, the presence of qualitatively heterogeneous properties and elements determine the need for the topic under study. In these conditions, scientific knowledge of the properties and principles of the functioning and development of economic systems and the use of this knowledge in the development of their models is necessary [12-13]. To account for the transformation processes in the economy, attention is paid to the methods of adaptive planning and management in economic and production systems [14].

For the synthesis of adaptive control systems, the theory of information and the integral method of pattern recognition and decision-making can be applied [15-16]. A knowledge-based economy, or a cognitive economy, includes as a basic element of understanding how subjects of different nature (individuals, groups and working groups, organizations) form their own actions in the economic space, that is how they formulate purposes, define alternatives, fix restrictions, make choices and introspect the achieved result [17-18]. With the help of cognitive modelling, the functioning of weakly structured complex economic systems receives solutions to systemic tasks, namely: object identification, cognitive model analysis, scenario analysis, forecasting, stability analysis, the model sensitivity and adaptability analysis, and decision making [19-20]. It is advisable to use the notion of utility and probability for evaluating a managerial decision [21].

A number of issues related to improving the management of the economic system, which is characterized by multicriteria, poorly structured and poorly formalized, require new approaches to modeling. Such an economic system will be considered as an object of management.

\section{Modeling of the Economic System. Prerequisites for the Use of Cognitive Technology}

The task of the choice or development of a mathematical model of the object of management is solved in the work while creating a rational of managerial decisions support making system. Such a model should provide adjustment to the specifics of the control object by using a posteriori information about it and the environment, as well as due to additional on-line information during the system exploitation.

Therefore, this model must realize the generation of such a set of controlled factors, the actual impact of which on the economic system in the next cycle of management with the highest possible probability will convert it into a predefined purpose state.

Thus, the model of a complex economic object should take into account:

- the current state of the and the trajectory in which it has converted into this state;

- the impact of existing and forecasted uncontrolled environmental factors on the behaviour of the object of management;

- previous experience of the real influence of control factors on the behaviour of the object of management.

It should be noted that this model has a limitation. It consists in the following: due to the complexity of processes occurring in the object of management, under the influence of external or internal uncontrolled factors (perturbations), a change in the object of management itself may occur.

Overall, the model of economic management object must solve two global tasks:
1. Identification of the current state of the object of management.

2. Managerial decision making.

For example, the parameters can be shared into four groups that characterize [5]:

- previous history of the object of management and the environment;

- a description of the actual state of the object and the environment;

- the human-independent factors;

- the human-dependent factors (managerial effects on the object of management).

The model of a complex object of management contains generalized factual information about what management actions previously in practice converted the complex object of management in a certain state and with such a previous history into a given purpose state. On the basis of this information a decision on the choice of managerial impacts is made.

In order to concretize this model, which allows the most adequately describe a complex object of management, the most rational approaches to the analysis of evaluation and decisionmaking are selected:

1. The system management approach assumes that any system or object is considered as a set of interconnected components. They are the exit from the system, the purpose, the input, the connection with the external environment, feedback.

2. The marketing approach of management is associated with the orientation of the consumer in the context of solving any problems. The main criteria of a marketing approach are:

- improving the quality of the management object in accordance with the requirements of consumers;

- economy of means of the consumer at the expense of improvement of quality;

- $\quad$ economy of resources in own production due to factors of production volume, scientific and technological advance, as well as application of scientifically grounded management system.

3. Behavioral approach for the decision estimation uses the concept of utility and probability.

4. Cognitive and procedural approaches involve the use of knowledge gained with the accumulation of experience in solving practical tasks and cognitive strategies mastered by the decision maker in the decision-making process. With a process management approach management functions are considered in their interrelation. The management process provides execution of all its functions, it is a series of continuous interrelated actions.

5. The essentially situational approach to management is that the degree of appropriateness of individual management methods is determined by the specific situation. In a particular situation, the method that most closely matches the situation will be most effective.

6. Managerial decisions support provides identification of the purpose of management, the development of a general analytical structure of the solution and the structuring of "value trees". An important task in designing a decision support system is the decision-making modelling and the development of solutions information support.

The estimation of the management object state is based on the monitoring of the indicators of its functioning at present and the diagnostics of such a state taking into account the potential resources of the business entity.

7. The economic status of an object of management depends on the set of indicators defined by the researcher. The variability of values of this set is determined by a complex of conditions, from evaluation methods of this status and from the chosen classification criterion and classification scale.

The analysis of tasks solved in economic object management systems shows that: 
- the technology for economic system status monitoring, the decision obtainment and making with elements of uncertainty should be flexible;

- the processes of the decision obtainment and making are based on qualitative and quantitative characteristics of the status of the economic object;

- attention should be paid to the two components of the process of the decision obtainment and making. They are those that are controlled by the decision maker and those that can be fulfilled using information technology.

The solution of this problem is proposed by means of the application of a cognitive approach to the management of the economic system. This approach is based on the results of processes of perception, understanding, knowledge, explanation and intellection. The essence of cognitive (cognitive) modelling is to display the most complex problems and tendencies of system development in the form of a model, to explore possible scenarios for the emergence of crisis situations, to find methods and conditions for their solution in a model situation. The use of cognitive models qualitatively raises the justification of managerial decisions making in a complex rapidly changed situation, deprives the expert from «intuitive wandering» and saves time for understanding and interpreting events that occur in the system $[22,23]$.

\section{Scheme of Cognitive Approach in the Managerial Decision Support Systems}

The below figure 1 architectural design describes that the Managerial Decision Support making consists of the few stages. At the first stage of the cognitive structuring of knowledge about the research object, it is proposed to apply progressive methods of strategic analysis such as PEST and SWOT analysis. The preliminary analysis of the economic system indicators is carried out with the use of such methods as correlation and cluster analysis. The next stage includes the construction of a cognitive model - formalization of knowledge using the structural analytical method of pattern recognition, which involves establishing and substantiating the interrelations between factors, further interpreting the results and identifying trends in the development of the object. After that, strategies for managing the situation around the economic system based on cognitive analysis are developed, providing the choice of management strategies based on information profiles of the research object.

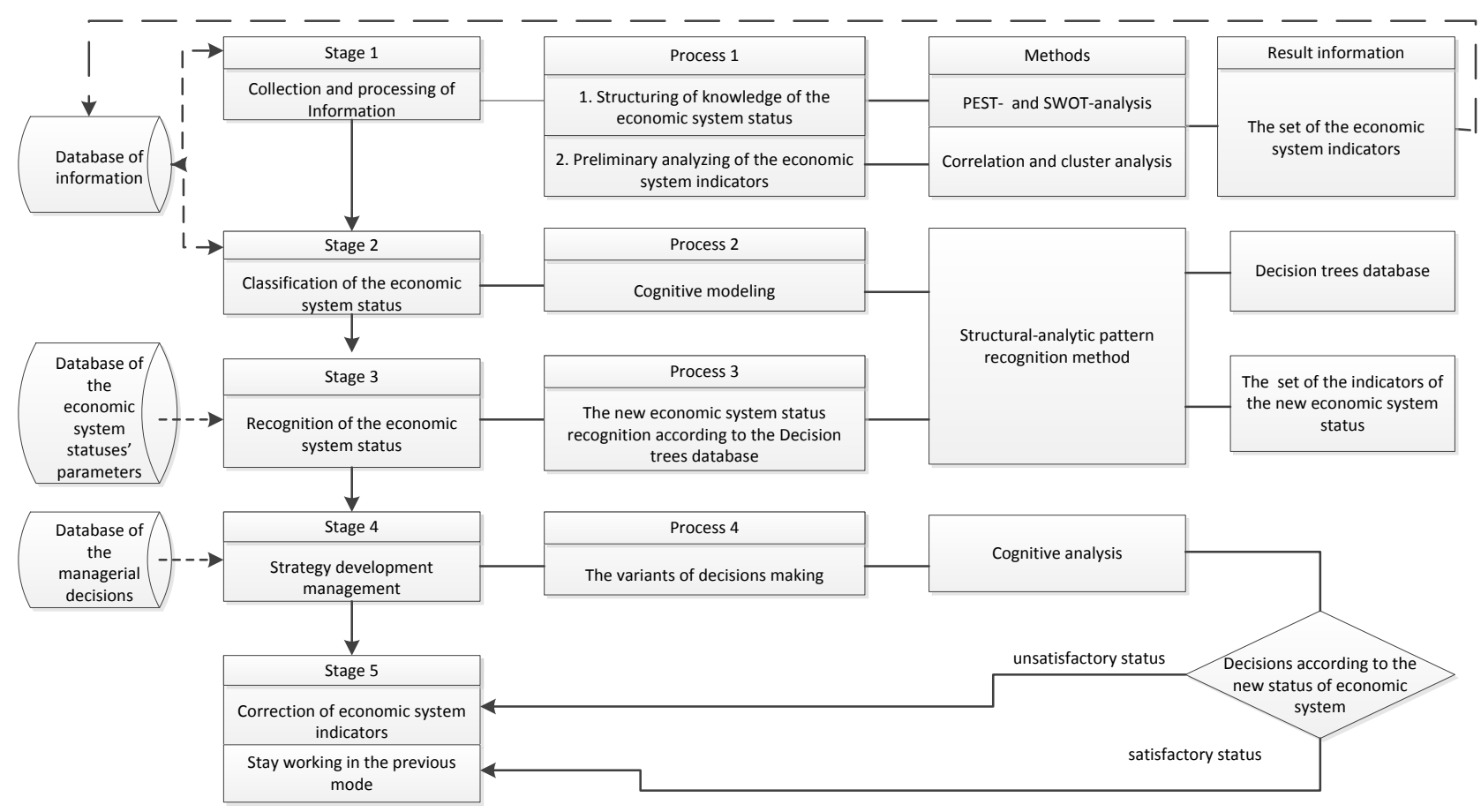

Fig.1: Scheme of cognitive approach in the Managerial Decision Support making Systems

\section{Cognitive Modelling of Economic Systems Based on the Theory of Pattern Recognition}

Within the framework of the cognitive approach, we propose to use the structural-analytic pattern recognition method based on identification of the system key elements and the establishment of interconnections or the allocation of the main factors that determine the status and development of economic systems and processes. The combination of the main factors and their level of influence on the object of research is the conceptual basis of the model [22]. There are reasons for applying image recognition methods, such as:

- the possibility of finding hidden patterns based on the analysis of archival data and classifiers;
- data verification;

- the use of mixed information (quantitative and qualitative); the requirement of flexibility of the status monitoring apparatus, making managerial decisions with elements of uncertainty;

- the necessity of two stages in the process of creating and making decisions: obtaining a solution as a result of the information technology work and a solution controlled by a specialist;

- obtaining meaningful results based on a small amount of input information with the possibility of further model improvement with new data.

The model of the economic system development as a set of models for the object description has been formulated to develop the cognitive methodology of economic systems modeling: 
$M=\left\{M_{0}, M_{E}, M_{U}\right\}$

Where $M_{0}-$ model of the economic system (object model); $M_{E}-$ model of the environment; $M_{U}$ - model of managerial system. The model of economic system, in order to achieve strategic reference points by reacting to external and internal changes, is:

$M_{0}(X, Z(X), U, P) \rightarrow \max \min (X, Z(X), U, P)$.

Where $X$ - parameters and controlling factors of the economic system (object) status; $Z(X)$ - uncertain and unmanaged factors; $U$ - managerial parameter;

$P$ - resources vector.

The model of the environment has uncertain and uncontrolled factors $M E=M E(Z)$.

The model of managerial system, taking into account the abovementioned approaches to the analysis of evaluation and decisionmaking, is based on the requirements of pattern recognition:

$M_{U}=\{D, K, C\}$

Where $D$-information database containing data on the interaction of the object and environment, system behaviour and results of measuring the state of the system and the environment; $K$ information base of knowledge about targeted management decisions. It includes the knowledge of the "supervisor" and the rules for choosing the process of changing the object status; $C$ interpretation of managerial decisions for the current information set about the economic status of the object of management.

The proposed research mechanism of phenomena and processes in the economic system in order to predict possible ways of its development or management of situations and adaptation to them will help to reduce the risk of the human factor.

The structural-analytical model of pattern recognition has been proposed [24, 25]:

$\left\{X_{n}, Y, F, B, L, W\right\}$.

Where $X_{n}$ - the space of attribute; $Y$ - the set of elements of the recognizable classes alphabet; $F: X_{n} \rightarrow F(X)$ - the closure ratio $X_{n}$, which postulates the data structure and the defining element of the classification rule structure in the form of the attribute-predicate; $B: F \rightarrow\{0,1\}$ - the reflection on the Boolean algebra, characterizes the logical structure of the pattern; $L:\langle F, B>\rightarrow Y-$ the classification rule; $W$ - the cost of the recognition system.

For the implementation of the structural-analytical pattern recognition method, an integrated system of automated processing of enterprise status indicators measured in different scales (quantitative, logical, order and names) has been used, which allows obtaining a mathematical model for assessing the enterprise status not in the form of a formulas system, but in a structural form (decision tree). The classification rules of the diagnostic of the new economic system status have been formulated based on the obtained structural-analytical models.

\section{The Results of Cognitive Modelling of the Economic System Based on the Theory of Pattern Recognition}

The results of cognitive modelling for decision making support are presented in order to manage the economic status of the air transport enterprise of Ukraine.

The "object-attribute" matrix according to the financial and economic activity of the enterprise for twelve years has been derived in a table form. The values of twenty nine indicators (attributes) have been determined. At the primary data processing stage, a correlation and cluster analysis have been performed to determine the set of fourteen informative technical and economic indicators that characterize the enterprise' economic statuses [26]. Classification data processing has been done with the following quantitative and qualitative indicators: passenger traffic, cargo traffic, passengers trust level, profitability of services, profitability of sales, staff profitability, fixed-asset turnover ratio, staff turnover rate, inventory turnover ratio, payable turnover ratio, receivables turnover ratio, coverage ratio, own-fund ratio.

Reliability estimation of the forecast of the enterprise transition to another economic status is based on the value of the probabilistic classification error. In this example, the classification error is zero. Known economic statuses to which the enterprise may belong are as following [27]: good status (indicated by 1), satisfactory status (indicated by 2) and unsatisfactory status (indicated by 3 ). According to the results of the research, "good status" is characteristic for four years of air transport company activity, "satisfactory status" - for six years, "unsatisfactory status" - for two years of twelve. The task of determining the informative indicators describing the statuses of enterprises with the zero error classification has been set.

The software complex [28], which is used for classification data processing, provides the modes for extracting attributes, statuses and implementations (table rows). Seven experiments with the different attributes area have been completed. Mathematical models of enterprise statuses classification have been presented in a structural form (decision trees).

The decision tree (or classification rule) is a binary hierarchical structure, where the nodes have terminal separating functions (inequalities or equality), and at the vertices - the numbers of enterprise statuses (classes). The left branch of the tree is identified with the true statement about the class' separation and the right - with the false.

Terminal separating functions describe the local regularities of the structural pattern in the researching subject area. It is possible to build several classification rules for one training selection, which have different structural complexity.

The training of the pattern recognition for automated analysis of experimental data processing has to be provided with four tasks:

1) obtaining an informative set of attributes with a given value of structural completeness assessment; 2) the output of the informative attributes' set of the training selection; 3) determination of the basic terminal separating functions, which are included in all classification functions sets to construct the decision tree; 4) construction of the decision tree.

Three rational decision models have been chosen to analyse the economic data in order to achieve the reliable result of the classification of the future enterprise status and to take into account the most quantity of attributes.

The structures of three decision trees are shown in Figure 2.

For example, the classification rules or classification functions of the enterprise status according to the first decision tree are defined as follows:

1) for the unsatisfactory status of the enterprise (indicated by the number 3) there are two alternatives:

- the passengers trust level is not equal to 3 , the staff turnover rate is not less than 0.184 and the inventory turnover ratio is less than 41.6 ;

- the passengers trust level is 3 , the cargo traffic is more than 1.7 and the staff turnover rate is less than 0.184 ;

2 ) for the satisfactory status (number 2) there are two alternatives:

- the passengers trust level is not 3 and the inventory turnover ratio is not less than 41.6 ;

- the passengers trust level is 3 , the cargo traffic is less than 1.7 ;

3 ) for the good status (number 1) there are two alternatives:

- the passengers trust level not equal to 3, the staff turnover rate is less than 0.184 and the inventory turnover ratio is less than 41.6; 
- the passengers trust level is 3, the cargo traffic is at least 1.7 and the staff turnover rate is not less than 0.184 .
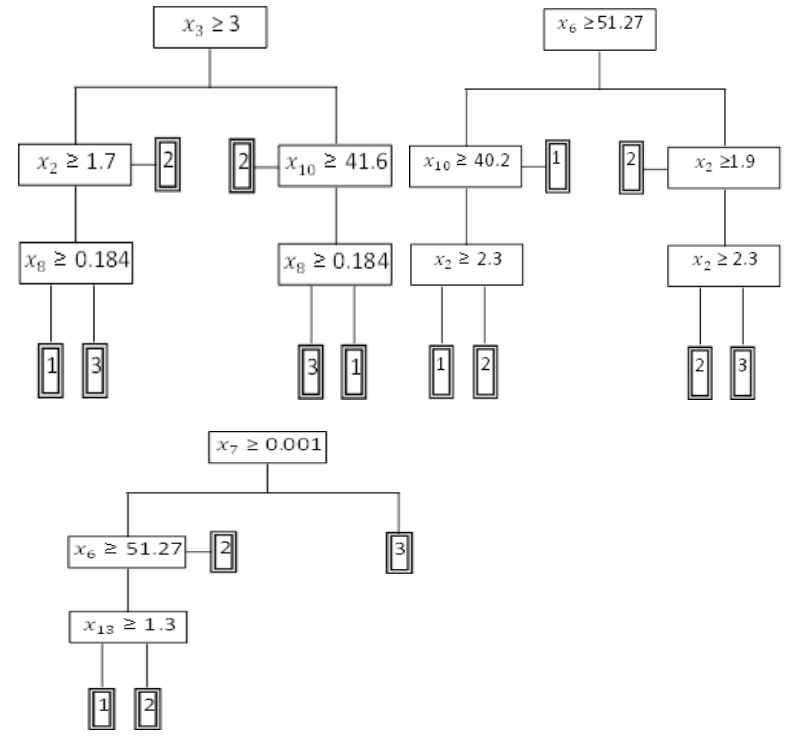

Fig. 2: The structures of the decision trees

We can identify the enterprise status using the obtained results according to the data of the new reporting period. The decision about the status of the enterprise is based on the most identical results of classification for each of the three decision trees. In the case of determining the enterprise status as "satisfactory" or "unsatisfactory" and the reasons for their occurrence, it is suggested to manage the values of the informative indicators. Forecasting of the probability of the enterprise transition to another status is based on the value of a probable classification error.

Structural-analytical model of pattern recognition as an effective tool to describe the structure of complex economic systems in the various types of attributes' space, as well as for obtaining managerial decisions making has been considered. The classification rules have to be placed in the knowledge base for conducting theoretical experiments and practical application solving real problems.

Thus, the proposed methodological approach to making managerial decisions in the transport industry allows achieving more effective management of enterprises in the constantly changing conditions of functioning and, consequently, their sustainable development.

\section{Conclusions}

Cognitive modeling as an instrument of intellectual decision support making in economic systems of the transport industry has been considered.

The modeling is based on the methods of pattern recognition theory. The results of scientific research are represented by structural-analytical models of decision support making system. Cognitive modeling will allow us to investigate the problems that arise in unstable, weakly structured environments (economic systems), to take into account changes in the external environment and the object of management itself, to systematize and verify the expert's perception of the object of management and its external environment, to forecast the significance of the factors of the economic system in objective conditions of the environment, generate optimal management strategies in changing dynamic conditions.

\section{References}

[1] Khomiakov V.I., Menedzhment pidpryiemstva, Kyiv, (2009), 430 p.

[2] Bazylevych V.D., Ekonomichna teoriia: Politekonomiia, Kyiv, Znannia, (2014), 710 p.
[3] Abalkyn L., "Ot ekonomycheskoi teoryy do kontseptsyy dolhosrochnoi stratehyy”, Voprosy ekonomyky, 6, (2010), p.49, available online: http://www.vopreco.ru/rus/redaction.files/6-10.pdf.

[4] Besedyn A.L., Teoryia upravlenyia sovremennoi orhanyzatsyei $v$ turbulentnoi sotsyalno-ekonomycheskoi srede: vyzhyvanye, reformyrovanye y razvytye, Tula, Yzd-vo TulHU, (2004), 352 p.

[5] Ansoff Y., Stratehycheskoe upravlenye, Moscow, Ekonomyka, (1989), $520 \mathrm{p}$.

[6] Lobanova Z.Y., Metodolohyia yssledovanyia ekonomycheskykh system, Moscow, YNFRA-M, (2007), 84 p.

[7] Skibitska L.I., Matvieiev V.V., Shchelkunov V.I. \& Podrieza S.M., Antykryzovyi menedzhment, Kyiv, Tsentr uchbovoi literatury, (2014), $584 \mathrm{p}$.

[8] Cherviachenko A.V., "Teoretychni pidkhody do vyznachennia efektyvnosti sotsialno-ekonomichnoi systemy ta yii vydova klasyfikatsiia", Ekonomika rozvytku, 1, (2014), pp. 46-48.

[9] Bakanov M.Y., Melnyk MV \& Sheremet AD, Teoryia ekonomycheskoho analyza, Moscow, Fynansy y statystyka, (2008), 536 p.

[10] Berdnykova TB, Analyz y dyahnostyka fynansovo-khoziaistvenno deiatelnosty predpryiatyia, Moscow, YNFRA-M, (2001), 215 p.

[11] Hammer M. \& Champy J., Reengineering the Corporation: A Manifesto for Business Revolution, Harper Collins Inc., New York, (1993), 332 p.

[12] Skurykhin V.Y, Zabrodskiy V.A., Ivashchenko P.A. \& Shtrasser O.H., Metody orhanyzatsyy adaptyvnoho planyrovanyia y upravlenyia $v$ ekonomyko-proyzvodstvennykh systemakh, Kiev, Nauk. dumka, (1980), $272 \mathrm{p}$.

[13] Romanov A.N. \& Odyntsov B.E., Sovetuiushchye ynformatsyonnye systemy v ekonomyke, Moscow, YuNYTY-DANA, (2000), p. 487.

[14] Kyzym N.A. \& Klebanova T.S., Adaptyvnye modely $v$ systemakh pryniatyia reshenyi, Kharkov, YD "Ynzhek", (2007), 368 p.

[15] Symankov V.S., Lutsenko E.V. \& Laptev V.N., Systemnyi analyz v adaptyvnom upravlenyy, Krasnodar, Yn-t sovr. tekhnol. y ekon., (2001), $258 \mathrm{p}$.

[16] Lutsenko E.V. \& Horpynchenko K.N., "Syntez systemno-kohnytyvnoi modely pryrodno-ekonomycheskoi systemy, yspolzovanye dlia prohnozyrovanyia y upravlenyia v zernovom proyzvodstve (Chast 3 Prohnozyrovanye y pryniatye reshenyi)", Nauchnyi zhurnal KubHAU, 90 (06), Krasnodar, KubHAU, (2013), available online: http://ej.kubagro.ru/2013/06/pdf/59.pdf.

[17] Bourgine P. \& Nadal J.-P., Cognitive Economics: An Interdisciplinary Approach, Berlin, Springer-verlag, (2004), 476 p.

[18] Walliser B, Cognitive Economics, Berlin Heidelberg, Springer-Verlag, (2008), $185 \mathrm{p}$

[19] Abdykeev N.M., Averkyn A.N. \& Efremova N.A., "Kohnytyvnaia ekonomyka v epokhu ynnovatsyi”, Vestnyk REA, 1, (2010), pp. 3-20.

[20] Horelova H.V., "Kohnytyvnyi podkhod k ymytatsyonnomu modelyrovanyiu slozhnykh system", Yzvestyia YuFU. Tekhnycheskye nauky, 3, (2013), pp. 239-250.

[21] Morhenshtern O, Dzh. fon Neiman, Teoryia yhr y ekonomycheskoe povedenye, Moscow, Knyha po Trebovanyiu, (2012), 708 p.

[22] Filipkovska L.O., "Metodolohiia kohnityvnoho modeliuvannia ekonomichnykh system na osnovi teorii rozpiznavannia obraziv", Sotsialno-ekonomichni aspekty rozvytku suspilstva: monohrafiia, Pid red. d-ra ekon. nauk, profesora Kyzyma M.O., Kharkiv, VD "Inzhek", (2014), pp. 201-218.

[23] Filipkovska L.O., "Korysnist u pryiniatti rishen za umov kohnityvnoho modeliuvannia v ekonomitsi", Suchasni problemy modeliuvannia sotsialno-ekonomichnykh system, Berdiansk, Vydavets Tkachuk O.V., (2016), pp. 58-60.

[24] Syrodzha Y.B., Stoian B.H., Protsenko V.S., Syrodzha Y.B. et al., "Strukturno-analytycheskyi metod mashynnoho raspoznavanyia obrazov s raznotypnymy pryznakamy", Teoryia R-funktsyi y aktualnye problemy prykladnoi matematyky, Kyev, (1986), pp. 212-244.

[25] Filipkovskaia L.A., "Yssledovanye strukturno-analytycheskoi modely raspoznavanyia obrazov v zadachakh upravlenyia y dyahnostyky", Problemy byonyky, 53, Kharkov, KhNURE, (2000), pp. 51-53.

[26] Filipkovska L.O., Matviienko O.O. \& Nikitenko S.V., "Formuvannia pervynnykh znan pro stany aviatransportnoho pidpryiemstva dlia diahnostuvannia yoho ekonomichnoi bezpeky”, Biznes Inform, 5 (448), Kharkiv, VD “Inzhek”, (2015), pp. 165-172.

[27] Yachmeneva V.M., "Predstavlenye ekonomycheskoi ustoichyvosty deiatelnosty predpryiatyi", Ekonomyka y upravlenye, 4-5, (2007), pp. 107-112.

[28] Filipkovskaia L.A., "Ynformatsyonnaia tekhnolohyia klassyfykatsyonnoi obrabotky dannykh proyzvodstvennykh sytuatsyi", Visn. Nats. tekhn. un-ta "Khark. politekhn. in-t", 7, Kharkov, NTU "KhPI", (2003), pp. 93-98. 